\title{
Studying the Effect of Silica Fumes on Mechanical Properties of Pervious Concrete
}

\author{
Himanshi Kashyap ${ }^{a}$ \\ Postgraduate Student, \\ Department of Civil Engineering, \\ Chandigarh University, Mohali, Punjab, 140413, India
}

\author{
Abhishek Singh Rana ${ }^{\mathrm{b}}$ \\ Assistant Professor, \\ Department of Civil Engineering, \\ Chandigarh University, Mohali, Punjab, 140413, India
}

\author{
Aditya Tiwaric \\ Assistant Professor, \\ Department of Civil Engineering, \\ Chandigarh University, Mohali, Punjab, 140413, India
}

\begin{abstract}
Today, concrete is the most widely used construction material throughout the world. But with the increase in the use of concrete, environment is also being affected. Other than issues like carbon emission by concrete, decrease in groundwater table level is also an important issue that should not be overlooked. Bitumen roads or impermeable roads do not allow the rainwater to penetrate through them as they are highly dense. Due to which stormwater is wasted that leads to decrease in groundwater table level. This study discusses the effect of partial replacement of cement with silica fumes on mechanical properties of pervious concrete. The ratios of replacement of silica fumes vary from $10 \%$ to $30 \%$ and curing period has taken are 7dayes and 28days. The main features of this research were to record the effects of different ratios of silica fumes on the mechanical properties of pervious concrete.
\end{abstract}

Keywords: Pervious concrete; silica fume; mechanical properties; pozzolana

\section{INTRODUCTION}

1.1 Pervious concrete - pervious concrete is a hunk of concrete with high porosity that is used for applications that allow stormwater to penetrate and reduce the runoff and recharge the underground water level. It is made of very little or no small aggregates. The paste of concrete covers the aggregate and water is allowed to pass through the concrete. It is used parking areas, roads with light traffic, housebound areas and greenhouses. It is a good example of sustainable construction, which is used by builder to enhance water quality. The main ingredients are cement, coarse aggregates, and water with little or no fine aggregates. The water-cement ratio is 0.28 to 0.40 and void content is $15 \%$ to $25 \%$. The right amount of water in the concrete is important. A low water-to-cement ratio increases the concrete's strength, but too little water can cause surface failure. A proper water content creates a wet-metallic appearance for the mixture. Pervious concrete has a typical strength of $600-1,500$ pounds per square inch $(4.1-10.3$ $\mathrm{MPa}$ ) although it is possible to achieve strengths of up to $4,000 \mathrm{psi}(28 \mathrm{MPa})$. Due to the unique structure, slump and air content measurements do not apply to pervious concrete. During the winter, using permeable concrete for pavements will make them safer for pedestrians as water will not pool on the ground and freeze, resulting in extreme icy conditions. The use of permeable concrete can also make roads safer for cars as reducing the accumulation of standing water would reduce the possibility of aquaplaning and porous roads will also reduce tire noise. Cleaning can be achieved by wetting the concrete surface or sweeping the vacuum. If roads are made with pervious concrete, it can pass stormwater at a rate of 3 to 5 gallons /minute/ square foot of area, exceeding the flow rate required to reduce the wastage of stormwater in most rain events. The rainwater can be collected under the pavement or allow in a coarse gravel layer. Because the road itself serves as a drainage zone, lot of the usually polluted runoff with impermeable pavements is avoided. As the water flows into open pavement cells, aerobic vortex bacteria contribute to the destruction of harmful pollutants and chemical agents.

A pervious concrete pavement can:

1. Reduce the quantity of untreated runoff to storm sewers.

2. Recharge the groundwater directly to protect the aquifer levels.

3. Flow more water to the roots and landscaping of the plant, so irrigation is less needed.

4. Mitigates the impacts of aquatic pollution and destroys fragile habitats.

5. Elimination of emissions of hydrocarbons from asphalt and sealants.

Because the paves in the front of the roof are vivid in color, and the framework of the open cell, pervious concrete floors do not absorb heat and retain it. The open void structure of the perpendicular paving allows the paving to cool down earth temperatures.

\subsection{Pozzolana-}

Pozzolanas, can be described as materials that, although not cemented in themselves, contain components that, in the presence of water, combine with lime to form solid, insoluble compounds with 
cementing properties. Mainly volcanic dust and ash products are natural pulpits.

Pozzolana cannot eliminate all problems of durability but it can help solve some of them if properly applied. The principal conclusion on the strength of the horn can be outlined below the impact of pozzolanic materials. In particular, pozzolans improve the resistance to environmental attacks by increasing the permeability, absorption, and diffusiveness of ions. Pozzolana does not adversely impact the depth of carbonation if concrete is compared with the same strength. When substituting pozzolanic materials for Portland concrete, tolerance to pure and acidic waters is definitely increased. Pozzolana decreases the spread of aggressive ions like chloride into concrete. In both ordinary Portland cement and sulphate resistant Portland cement, naturally occurring pozzolana, fly ash and silica fumes decrease expansion, mass alteration as well as strength loss when contained for sodium sulfates. If the pozzolanic content replaces ordinary Portland cement, the loss of mortaring capacity exposed to magnesium sulfate solutions is slowed. Up to 25 percent of hydrated Portland cement is made of calcium hydroxide (lime), and lime does not add to the strength and toughness of the concrete. Pozzolana combines with lime the substance responsible for holding together the concrete to produce additional calcium silicate hydrate.

By consuming the excess lime:

The concrete strength is increased

1. The thickness of the concrete is increased

2. The efflorescence level decreases

Typical pozzolana include:

Metakaolin

1. Silica fume

2. Fly ash

3. Slag

4. VCAS (vitrified calcium alumino-silicate)

Silica fumes is the most reactive, with metakaolin close to silica fumes in terms of reactivity. Fly ash is less reactive, especially during the first few days of curing when less calcium hydroxide is produced. Generally, the finer the pozzolana particles are, the more reactive they are. Silica fumes is the finest with most particles having an average of $0.3 \mu \mathrm{m}$ (microns), metakaolin has an average of about $4 \mu \mathrm{m}$, Portland cement has an average of about $15 \mu \mathrm{m}$, and fly ash has an average of about $70 \mu \mathrm{m}$.

\section{Physical Requirements-}

Fineness: the specific surface of Portland-pozzolana cement shall not be less than $300 \mathrm{~m} 2 / \mathrm{kg}$ when tested using the air permeability method described in IS 4031 (Part 2): 1988.

Soundness: When tested by Le Chatelier method and autoclave test as described in IS 4031 (Part 3): 1988, untreated Portland-pozzolana cement Average drying shrinkage of mortar bars shall not be extended by more than $10 \mathrm{~mm}$ and $0.8 \%$, respectively.

Setting period: The setting time of Portland-pozzolana concrete, when measured using the Vicat apparatus method described in IS 4031 (Part 5): 1988, shall be 30min (Minimum) for the initial set time and 600min (Maximum) for the final set time Compressive strength.

\subsection{Silica fumes-}

Silica fumes, also known as micro silica, is an amorphous (non-crystalline) polymorphic silicon dioxide, silica. This ultrafine powder consisted of spherical particles with an average part diameter of 150 $\mathrm{nm}$, collected from the production of silicone and Ferrosilicon alloys. The main field of application is as high-performance concrete pozzolanic material. Silica fume is an ultrafine substance of fewer than $1 \mu \mathrm{m}$ in diameter with a mean of approximately $0.15 \mu \mathrm{m}$ spherical particles. This reduces it to about 100 times the average cement particle. The bulk density of silica fume varies from 130 to $600 \mathrm{~kg} / \mathrm{m} 3$ and depends on the degree of silo densification. The general intensity of the silica fume is normally between 2.2 and 2.3. Silica fumes are added to Portland concrete in order to improve its properties, particularly its resistance to compression, bending, and abrasion. Such changes are both caused by the mechanical improvements induced by the application of a very thin powder to the cement paste mix and the pozzolana reactions between the silica fume and free calcium hydroxides in the pulp. Silica fume has an effect on different characteristics of fresh and hardened concrete:

Workability: The slump loss is directly proportional to the introduction of silica fume with time to increase the silica fume content because the large surface area is added in the concrete mix by its inclusion. The combination remains highly stable, though the slump decreases.

Segregation and bleeding: the fume of silica reduces bleeding greatly since the wetting of the large silica fume layer absorbs free water and therefore also decreases the amount of free water remaining in the bleeding mix. Silica fume also blocks the pores of the fresh cement to prevent the water from entering the surface within the concrete. If silica fume is applied to cement, initially it stays inert. When Portland concrete and water in the mix begin to respond (hydration), two chemical compounds create the key chemical reactions. The Calcium Silicate Hydrate ( $\mathrm{CSH})$, which is the crystallizing force, and the Calcium Hydroxide $(\mathrm{CH})$, a by-product that is also called free chalk, which only drops on pores that are usable as a filler or leaching plaster. Pozzolana reactions occur between silica and $\mathrm{CH}$, which in many of the voids surrounding hydrated cement particles creates additional CSH. This additional $\mathrm{CSH}$ not only enhances the compressive, bending and attachment strength of the concrete but also provides a dense matrix, especially in areas where deleterious materials will remain as small vacuums. 


\section{LITERATURE REVIEW}

Prakash et.al researched and evaluated the cost-effective and environmentally friendly solution of perpendicular concrete to promote sustainable buildings. Pervious concrete is manufactured without fines and the compressive strength of the grade OPC53 compared with any other mixing ration is strongest.

Jiusu et.al analyzed that SF is more efficient in generating lower RAC strength, which is mainly due to the higher packing densities of different mixtures of Blast furnace slag, Fly ash and Silica Fume. In order to achieve satisfactory workability and strength, ITZ confirm that new mixing technique coating with pozzolanic powder contributes to a dense ITZ structure. Therefore, by using the new mixing technique the internal bleeding potential can be reduced.

Vikram et.al has researched and analyzed the decrease in the slump with the addition of silica flume in pervious concrete mixed proportions. The compaction factor was improved with the addition of silica fume in the pervious concrete mixing proportions. With the introduction of the silica plant, the flow efficiency of pervious mixing ratios of concrete has improved.

Sriravindrarajah et.al researched that recycled concrete aggregate reduced the compressive strength of perennial concrete so that it is useful for use in pavements and is not suitable for construction purposes. The increased porosity of pervious concrete decreased in aggregate volume, thereby increasing the strength of pervious concrete. The compressive strength of the forehead concrete mainly depends upon the porosity of the concrete; the age, form, and volume of test materials showed a marginal impact on pervious concrete's strength for a porosity

Murthy et.al studied that the strength of pervious concrete is improved by adding 5 percent Robo sand as fine aggregate and 100 percent (80 percent $s 1+20$ percent s2) gross aggregate in the mix strength increased in the remaining mixtures by varying the percentages of Fine and Gross Aggregate. - Improved Pervious Concrete Produces Compressive Strength Of 19.54N / Mm2 And 20.44N / Mm2 At 28 Days Of Hydration Time Adding 2.5 Percent And 5 Percent Fine Aggregates (Robo Sand) And Maintained Constant Volume Of Coarse Aggregates (90 Percent S1+ 10 Percent S2) In Respective Mixes. Through addition of the Fine Aggregate and 10 percent of the S2 gross aggregates, the vacuums decreased in the mixtures and improved strength and decrement of permeability.

Patil et.al researched the use of strong and durable pervious concrete mixtures for low-volume roads. The result of two forms of fine aggregates, i.e. Crushed Stone and River Sand has been tested on various properties of pervious concrete. The fine aggregate to gross aggregate ratio was 1:5,720 compared to conventional pervious cement concrete mixtures. Cement content ranged from $300 \mathrm{~kg} / \mathrm{m} 3$ to 340 $\mathrm{kg} / \mathrm{m} 3$ with an increase of $10 \mathrm{~kg} / \mathrm{m} 3$. A maximum of 10 different pervious concrete mixtures were prepared to take into account each degree of cement content and each form of fine aggregate. In addition, steel fiber has been used to increase the strength factor.
Kovác et.al studied that decreased w / c ratio cause fresh pervious concrete to be stiffer and therefore more difficult to process despite the use of a higher volume of plasticizer. This is likely to result in unexpectedly lower unit weight, higher void size, and higher hydraulic conductivity. Only very small differences in the strength characteristics of pervious concrete were caused by the test range of $\mathrm{w} / \mathrm{c}$ ratio, but virtually enough values were obtained.

Rajeshvarsinh et.al focuses on retaining substantial environmental and economic benefits in the sense of pervious concrete, having high compressive strength and maximum permeability. A scheme has been developed to ensure that environmentally friendly, optimal compressive, tensile, flexural and strong permeable concrete can be achieved.

Saboo et.al studied the effects on characteristics of perishable concrete of fly ash, metakaolin, and cure. The interaction plots showed that the addition of $2 \%$ metakaolin decreased porosity and significantly increased size. There has also been a similar sort of finding of fly ash. The rate of change in properties for fly ash was between 5 and $15 \%$ higher

Lu et.al studied the pervious concrete with single coarsesize aggregates that had significantly greater permeability, but lower compression capacity compared with PCs prepared with a single small aggregate. Nevertheless, the use of silica fume as cement materials in 10 percent can significantly improve compressive strength while correspondingly decreasing the permeability of PCs. If WGC and RCA were used to replace the natural single-size aggregates, compression resistance was reduced due to the reduction in density and poor association between pulp and aggregates.

Liu et.al researched that the surface treatment with the emulsion of silane polymer is effective for enhancing RA strength while maintaining a good permeability of pervious concrete. Samples with high porosity and low cement content had stronger characteristics, such as increased strength.

Samee et.al studied that for 28 days of curing with Silica Fume Mix, the pervious hormone was reached, the compressive strength was $17.0 \mathrm{~N} / \mathrm{mm} 2,9.01 \mathrm{~N} / \mathrm{mm} 2$ and $6.32 \mathrm{~N} / \mathrm{mm} 2$ respectively for the mixing ratio of $1: 4,1: 6$ and $1: 8$. Whereas the strength of pervious concrete is $9.14 \mathrm{~N} /$ $\mathrm{mm} 2,5.92 \mathrm{~N} / \mathrm{mm} 2,4.28 \mathrm{~N} / \mathrm{mm} 2$ for mixed ratio of $1: 4$, $1: 6$ and 1:8 respectively after 28 days of curing without any mixture of admixtures. The production of compressive strength for Silica Fume mixed pervious concrete with a higher force for all mixed ratios and all the stages of curing than pervious concrete without Silica Fume.

\section{CONCLUSION-}

The main aim of the study was to find the effect of different ratios of silica fume, fly ash, metakaolin at different curing period. It was also found that as water-cement ratio decreases, the permeability decreases and the resistance increases. Permeability and strength of porous concrete can change with various replacements like Fly Ash, Silica Fumes. Pervious concrete made with no fines and with 
OPC53 grade cement has highest compressive strength. The mean compressive strength developed at 7day and 28-day when the cement replacement by pozzolan increases by $10 \%$ than without pozzolan. Compressive Strength of pervious concrete depends on the size and quantity of RCA used. Achievement of eco-friendly and permeable concrete with optimum compressive, tensile and flexural strength.

\section{REFERENCES}

[1] Ajamu, S.O., Jimoh, A.A., Olurem, I J.R., (2012) "Evaluation of Structural Performance of Pervious Concrete in Construction", International Journal of Engineering and technology.

[2] Agilandeswari, N.H., Ashif, J.H., Sharafath, M., Vadivel, B., Renukadevy, R., (2017)."An Experimental Study on Performance of Pervious Concrete Using Partial Replacement of Recycled Concrete Aggregate" International Journal of Innovative Research in Science, Engineering and Technology, ISSN: 2319-8753.

[3] Chen, Y., Wang, K., Wang, X., (2013) "Strength, fracture and fatigue of pervious concrete", Construction and Building Material, 'Elsevier'.

[4] Chakravarti, B. J., Sushmita, B., Murthy, K.N.R., (2019). "Study on pervious concrete" International Journal of Civil Engineering and Technology ISSN: 0976-6316.

[5] Damirboga R., "Thermal conductivity and compressive strength of expanded perlite aggregate concrete with mineral admixtures", Energy and Buildings, Elsevier, September 2003

[6] Htay, H. H., Aung, H. T., (2018). "Study on Natural Pozzolana as a partial replacement in pervious concrete" International journal of a trend in scientific research and development, ISSN: 2456-6470.

[7] IS-3812(2)-2013: Pulverised Fuel Ash Specification

[8] IS-15388(2003): Silica Fume-Specification

[9] IS-516(1959): Methods of Tests for Strength of Concrete.

[10] Ibrahim, A., Mahmoud, E., Yamin, M., "Experimental study on Portland cement pervious concrete mechanical and hydrological properties", Construction and building materials, 'Elsevier'.

[11] Jiusu, L., Hanning, X., Yong Z., (2008).” Influence of coating recycled aggregate surface with pozzolanic powder on properties of recycled aggregate concrete", Construction and Building Materials 23 (2009) 1287-1291.

[12] Joao Virgilio Merighi, Rita Moura Fortes, Alex Bandeira, July 2006, "Study Of the Concept of Porous Concrete for Use on Airport Runway". 25th Southern African Transport Conference, July 10-13 2006, Isbn No:-1-920-01706-2, Pp. 44-53

[13] Jayanta Bandyopadhyay, Ratanamani Chakraborty, Shibasish Deb, 2015, "Comparative Study on Various Parameters of Pervious Concrete for Different Size of Coarse Aggregates". International Journal Of Research And Analytical, Vol 2, Issue 2, June 2015, Issn:- 2349-5138, Pp. 123-129

[14] Kumar, S., Sharma, D., Kumar, N. (2017). "Paper on Permeable Concrete as A Road Pavement" International Research Journal of Engineering and Technology, ISSN: 2395-0056.

[15] Lu, J. X., Yan, X., He, P., Poon, C. S., (2019) "Sustainable design of pervious concrete using waste glass and recycled concrete aggregate" Construction and Building Material, 'Elsevier'.

[16] Liu, T., Wang, Z., Zou, D., Zhou, A., Du, J., "Strength enhancement of recycled aggregate pervious concrete using a cement paste redistribution method" Construction and Building Material, 'Elsevier'.

[17] M. Harshavarthana Balaji, M.R. Amarnath, R.A. Kavin, S. Jaya Pradeep, February 2015, "Design Of Eco-Friendly Pervious Concrete".International Journal Of Civil Engineering And Technology, Vol 6, Issue 2, February 2015, Issn 0976-6316, Pp. 22-29

[18] Meng, X., Chi, Y., Jiang, Q., Liu, R., (2019) "Experimental investigation on the flexural behavior of pervious concrete beams reinforced with geogrids" Construction and Building Material 'Elsevier'.

[19] Nishith M. N., Acharya, G., Ahmed, S. K., (2016) "Experimental study on the implementation of pervious pavements", International Journal of Innovative Science, Engineering \& Technology.

[20] NEVILLE A.M., "Concrete technology"
[21] Parikh K.B., Shaik M.A., Haji Adil, March 2016 "Experimental Investigation Of Mineral Admixture In Pervious Concrete" International Journal Of Scientifics \&Research Publication, Vol 6 , Issue 3, March 2016, Issn 2250-3153, Pp. 84-87

[22] Prakash, V., Chandraseka, K., Vinoth, P., (2018). "Partial Replacement of Silica Fume and Fly Ash in Pervious Concrete", International Research Journal of Engineering and Technology, ISSN: 2395-0056.

[23] Rajeshvarsinh, A., Jadeja, Krunal J. D., (2017). "Experimenta Studies on Pervious Concrete Utilizing GGBFS and Silica Fume as a Partial Replacement of Cement" International Journal for Research in Applied Science \& Engineering Technology, ISSN (O)-2395-4396.

[24] SilAmitva, Kumar D., Roy Singha, "Performance of High Volume Fly Ash Concrete Using Local Power Plant Fly Ash", Internationa Journal of Composite and Constituent Materials journals pub, 2015

[25] Sabet F.,Libre N, Shekarchi M., "Mechanical and durability properties of consolidating high-performance concrete incorporating natural zeolite, silica fume and fly ash."

[26] SHETTY M.S., "Concrete technology : theory and practice"

[27] Saboo, N., Shivhare, S., Kori, K.K., Chandrappa, K.A., (2019) "Effect of fly ash and metakaolin on pervious concrete properties" Construction And Building Material 'Elsevier' 322-328.

[28] Sahdeo, S. K., Ransinchung, G.D., Nandi, S., (2019). "Performance of Pervious Concrete Pavement Incorporating Different Waste Materials" International Conference on Transportation Infrastructure Projects Conception to Execution, ISSN: 2321-9653.

[29] Tabatabaeian, M., Khaloo, A., Khaloo, H., (2019) "An innovative high-performance pervious concrete with polyester and epoxy resins" Construction And Building Material, 'Elsevier'

[30] Vikram, Mahla, R.P., (2018). "Experimental Study of Pervious Concrete Pavement" International Journal for Research in Applied Science \& Engineering Technology, Volume 3 Issue VII ISSN: 2321-9653.

[31] Yasar E, Duran C, Kilic A., Gulsen H., (2003) "Strength properties of lightweight concrete made with basaltic pumice and fly ash", construction materials, Elsevier, November. 